Melike Arabac1 ${ }^{1}$, Nuray Doğan ${ }^{1}$, Mustafa Tokdemir ${ }^{1}$, Yusuf Adnan Güçlü ${ }^{1}$, Haluk Mergen ${ }^{1}$, Kurtuluş Öngel ${ }^{2}$

${ }^{1}$ Tepecik Education and Research Hospital, Department of Family Medicine, İzmir, Turkey

${ }^{2}$ İzmir Katip Çelebi Unıversity, Faculty of Medicine,

Department of Family Medicine, İzmir, Turkey

\section{Hyperosmolar hyperglycemic nonketotic syndrome in a Turkish family medicine clinic}

\section{Abstract}

Introduction: Hyperosmolar Hyperglycemic Nonketotic Syndrome (HHNS) is a complication of Diabetes mellitus observed with high serum glucose, absence of ketone bodies and high hyperosmolarity. HHNS is a medical emergency requiring prompt recognition and treatment.

Case report: A 52 year old diabetic Turkish woman is admitted to our institution with +2 positive excretion of glucose in urine, high level of plasma glucose of $515 \mathrm{mg} / \mathrm{dL}$ and hiperosmolality $(328 \mathrm{mOsm} / \mathrm{kg})$. A careful treatment with intravenous fluids, potassium and use of insulin $(0.1 \mathrm{U} / \mathrm{kg}$ IV bolus and continuous IV infusion of $0.1 \mathrm{U} / \mathrm{kg}$ ). When her plasma glucose level decreased to normal levels, the patient was discharged with commitments for her effective diabetes therapy.

\section{Introduction}

Hyperosmolar Hyperglycemic Nonketotic Syndrome (HHNS) is a syndrome of abnormally high serum glucose and osmolarity coupled with depressed consciousness and an absence of ketoacidosis.

HHNS is a complication of diabetes mellitus which is a serious condition most frequently seen in older persons and it is usually caused by an illness or infection. It represents as many as 20 percent of all cases of severe hyperglycemia and constitutes a life-threatening medical emergency ${ }^{1}$.

It is related to diabetic ketoacidosis (or DKA) which is the another complication of the diabetes and they are differentiated from each other by the measurement of ketone bodies, organic molecules that are representative for DKA, while usually not detectable in HHNS. From $50 \%$ to $75 \%$ of hospitalized patients who have uncontrolled diabetes present with significant hyperosmolarity ${ }^{2}$.

An altered state of consciousness attributable to uncontrolled diabetes is virtually always the result of severe hyperosmolar hyperglycemia.
HHNS is a medical emergency that requires prompt recognition and treatment. Delayed diagnosis and treatment is one of the important factors responsible for the high mortality associated with $\mathrm{HHNS}^{3,4}$.

There is no symptom or sign specific of HHNS, and hence there is often a delay in seeking medical care. Patient typically have no prior knowledge of glucose intolerance, and experiences polyuria, polydipsia and weight loss, as osmotic diuresis sets in $^{5}$.

Usually, these patients at presentation have poor skin turgor, dry mucous membrane, tachycardia, low jugular venous pressure and maybe hypotensive ${ }^{6}$.

HHNS should include immediate determination of blood glucose, blood urea and creatinine, serum electrolytes, osmolarity and ketones and arterial blood gases.

The treatment of HHNS consists of correction of the dehydration with intravenous fluids and potassium and the judicious use of insulin $(0.1 \mathrm{U} / \mathrm{kg}$ IV bolus and after $0.1 \mathrm{U} / \mathrm{kg}$ IV), in conjunction with careful monitoring of central venous pressure and urine output, and management of any underlying conditions that might have precipitated the illness, such as an acute infection form the mainstays of treatment. 


\section{Case report}

A 52 year old Turkish woman was admitted to our institution with tiredness, lassitude, polyuria, dysuria symptoms. The patient didn't described any chronic illness or taking medicine. There was excretion of glucose in urine and in blood test the plasma glucose (greater than $515 \mathrm{mg} / \mathrm{dL}$ ) and the serum osmolarity (greater than $328 \mathrm{mOsm} / \mathrm{kg}$ ) was abnormal.

The patient has been hospitalized in Family Medicine Clinic with diagnosed with HHNS.. In physical examination, genital infection was found and treated. The treatment of HHNS has done with intravenous fluids (4 litres), potassium and intravenous of insulin $(0.1 \mathrm{U} / \mathrm{kg}$, IV bolus and after regular $0.1 \mathrm{U} / \mathrm{kg} \mathrm{IV).} \mathrm{After} \mathrm{that} \mathrm{her} \mathrm{plasma} \mathrm{glucose} \mathrm{is} \mathrm{decreased}$ to normal levels, the patient is discharged with special commitments for her illness.

\section{Conclusion}

HHNS is approximately $1 \%$ of hospitalized patients due to Type 2 diabetes (T2DM) ${ }^{6}$. Diagnosis of appropriate treatment should be started without delay. Life-threatening hyperglycemic hyperosmolar syndrome, which is characterized by severe hyperglycemia without ketoacidosis, and very high serum osmolarity and dehydration, appears to be rised in adolescents with extreme obesity and T2DM.

High index of suspicion in dehydrated patients who continue to have increased rather than decreased urine output may help in early diagnosis. The treatment guidelines recommend early restoration of the intravascular volume, correction of fluid and electrolyte deficits, hyperglycemia and hyperosmolarity.
Melike Arabacı ${ }^{l}$, Nuray Doğan ${ }^{l}$, Mustafa Tokdemirl, Yusuf Adnan Güçlül, Haluk Mergen ${ }^{1}$, Kurtuluş Öngel ${ }^{2}$

${ }^{1}$ Tepecik болница-истраживачки и образовни центар, Одељење опште медицине, Смирна, Турска

${ }^{2}$ Катип Челебија универзитет, Медицински факултет, Смирна, Турска

\section{Дијабетесно некетогено}

\section{хиперосмоларно стање у Турској клиници опште медицине}

\section{Сажетак}

\section{Кључне речи:}

\section{Дијабетес,}

компликације, хиперосмоларност, хипергликемија
Увод. Дијабетесно некетогено хиперосмолално стање је компликација дијабетес мелитуса, чије су карактеристике висок ниво глукозе у серуму, непостојање кетонских тела и изражена хиперосмоларност. То је хитно медицинско стање које захтева што брже постављање дијагнозе и почетак терапије.

Приказ случаја. Туркиња, дијабетичарка стара 52 године, примљена је у нашу установу са +2 позитивним налазом глукозе у урину, високом концентрацијом глукозе у плазми од $515 \mathrm{mg} / \mathrm{dL}$ и хиперосмоларношћу (328 $m O s m / k g)$. Проведена је терапија опрезном интравенском надокнадом течности и калијума и применом инсулина $(0,1 \mathrm{U} / \mathrm{kg}$ у интравенском болусу, праћена континуираном интравенском инфузијом $0,1 \mathrm{U} / \mathrm{kg}$ ). Када је ниво глукозе у плазми достигао нормалне вредности, пацијенткиња је отпуштена кући, са упутствима за ефикасну терапију дијабетеса. 


\section{Literatura}

\section{References}

1. Hyperosmolar hyperglycemic nonketotic coma. [http://www.ncbi.nlm.nih.gov/ pubmed/2680468] accessed on 11.8.2013.

2. Matz R Management of the hyperosmolar hyperglycemic syndrome. Mount Sinai School of Medicine of the City University of New York, USA. American Family Physician. 1999;60(5):1468-1476.

3. Hollander AS, Olney RC, Blackett PR, Marshall BA. Fatal malignant hyperthermia-like syndrome with rhabdomyolysis complicating the presentation of diabetes mellitus in adolescent males. Pediatrics 2003;111: 1447-1452.
4. Morales AE, Rosenbloom AL. Death caused by hyperglycemic hyperosmolar state at the onset of type 2 diabetes. $\mathrm{J}$ of Pediatr 2003;144:270-273.

5. Delaney MF, Zisman A, Kettyle WM. Diabetic ketoacidosis and hyperglycemic hyperosmolar non ketotic syndrome. Endocrinol Metab Clin North Am 2000; $29: 683-705$.
6. Diabetes Mellitus ve Komplikasyonlarının Tanı, Tedavi Ve İzlem Kılavuzu. Türkiye Endokrinoloji ve Metabolizma Derneği, 2011. [http://www.turkendokrin.org/files/ pdf/diabetes_klvz2011_web.pdf] accessed on 15.06.2013.

Примљен • Received: 14/01/2014

Прихваћен • Accepted: 20/02/2014 